\title{
Cetca:
}

\section{Mengingkatkan Kemampuan Guru Menulis Karya Ilmiah Dengan Menghadirkan Guru Tamu Di Sekolah}

\author{
I Nyoman Tingkat \\ SMA Negeri 2 Kuta Selatan \\ tingkat66@yahoo.com
}

DOI : $10.37329 /$ cetta.v3i1.411

\begin{tabular}{l}
\hline Keywords: \\
\hline Credit Score, \\
Promotion, Guest \\
Teacher, Article. \\
\hline
\end{tabular}

\begin{abstract}
The aim of this article is to know the effectiveness of the presence of a guest teacher for the teachers in SMA Negeri 1 Kuta Selatan to produce a various research. Since PKG (Penilaian Kinerja Guru) has been implementing from January 1, 2013, teachers could not have a promotion in 2 years if they were not an administrator or in IV/a level. It happened because it needed a credit score of the continuing professional development in every preferment if teachers wanted to have a promotion from III/a to III/b. Then, for III/b and above, they need to complete the credit score through a scientific publication and or an innovative work. This research used literature review, questionnaire, observation sheets and interview in collecting the data. Meanwhile the data analysis used was descriptive qualitative. The results showed two points. First, the presence of a guest teacher through a workshop in SMA $N 1$ Kuta Selatan could increase teachers' ability to produce a research and an innovative work. The impact was on the teacher's promotion in the first cycle from no one to three people $(7,69 \%)$ in the second cycle. The number of teachers who made proposal and were ready to present it in an academic conference were increasing from three people $(7,69 \%)$ in the first cycle to eight people $(20,51 \%)$ in the second cycle. Teachers who wrote scientific articles in an ISSN journal were also increasing from four people $(10,25 \%)$ in the first cycle to five people $(12,82 \%)$ in the second cycle. Second, the teachers' response were also increasing toward the presence of a guest teacher from $72,22 \%$, which was a neutral category in the first cycle, to $83,33 \%$, a good category in the second cycle. Its effect the students' achievements, from 72 medals in the first cycle to 88 medals in the second cycle.
\end{abstract}

\begin{tabular}{l}
\hline Kata Kunci: \\
\hline Angka Kredit, \\
Kenaikan \\
Pangkat, Guru \\
Tamu, Karya \\
tulis. \\
\hline
\end{tabular}

Abstrak
Tujuan artikel ini untuk mengetahui efektivitas kehadiran guru
tamu bagi guru SMA Negeri 1 Kuta Selatan dalam melahirkan
karya publikasi ilmiah dengan berbagai variannya. Sejak
diberlakukan sistem kenaikan pangkat melalui PKG (Penilaian
Kinerja Guru) mulai 1 Januari 2013, guru tidak bisa lagi naik
pangkat dalam 2 tahun sampai golongan IV/a. Hal ini terjadi




\begin{abstract}
karena setiap kenaikan pangkat ke golongan setingkat lebih tinggi sejak III/a ke III/b harus memenuhi angka kredit dari Pengembangan Keprofesian Berkelanjutan (PKB). Selanjutnya dari golongan III/b ke atas, wajib memenuhi angka kredit dari publikasi ilmiah dan/atau karya inovatif. Pengumpulan data dalam penulisan artikel ini menggunakan studi pustaka, kuesioner, lembar pengamatan, wawancara. Analisis data menggunakan analisis deskriptif kualitatif untuk selanjutnya ditarik simpulan. Hasil penelitian menyimpulkan dua hal. Pertama, kehadiran guru tamu melalui workshop di SMA Negeri 1 Kuta Selatan dapat meningkatkan kemampuan guru untuk menulis karya tulis ilmiah dan karya inovatif. Implikasinya berdampak pada kenaikan pangkat para guru dari 0 pada sikus I menjadi 3 orang $(7,69 \%)$ pada Siklus II. Guru yang membuat proposal dan siap tampil dalam Seminar Akademik meningkat dari 3 orang $(7,69)$ pada Siklus I menjadi 8 orang $(20,51 \%)$ pada Siklus II. Guru yang menulis artikel ilmiah di jurnal ber-ISSN meningkat dari 4 orang $(10,25 \%)$ pada Siklus I menjadi 5 orang $(12,82 \%)$ pada Siklus II. Kedua, respon guru juga mengalami peningkatan terhadap kehadiran guru tamu dari 72,22 \% dengan kategori Cukup pada Siklus I menjadi 83,33 \% dengan kategori Baik pada Siklus II. Meningkatnya respon positip guru juga dapat meningkatkan prestasi siswa, dari 72 medali pada Siklus I menjadi 88 medali pada Siklus II.
\end{abstract}

\title{
Pendahuluan
}

Sejak Peraturan Menteri Negara Pendayagunaan Aparatur Negara dan Reformasi Birokrasi Nomor 16 Tahun 2009 tentang Jabatan Fungsional Guru dan Angka Kreditnya, diberlakukan secara efektif mulai 1 Januari 2013, banyak guru yang tertunda kenaikan pangkatnya karena belum terpenuhinya kewajiban melakukan Pengembangan Keprofesian Berkelanjutan (PKB). PKB direspon oleh Anies Baswedan saat menjadi Mendikbud dengan meluncurkan Program Guru Pembelajar pada puncak peringatan Hardiknas di Jakarta pada 29 Mei 2016. Dalam sambutannya, Anies Baswedan antara lain mengatakan, "Guru harus terus-menerus belajar. Guru lebih dari sekadar mengajar, dia mendidik, menginspirasi, juga menggerakkan. Jika guru terbuka pada kebaruan, maka anak-anak akan mengikuti gurunya. Tujuannya tidak hanya memajukan siswa, tetapi juga untuk mengembangkan diri guru itu sendiri".

Program Guru Pembelajar dilanjutkan dengan Program Peningkatan Kompetensi Pembelajaran (PKP) oleh Menteri Pendidikan dan Kebudayaan, Muhadjir Effendy, mulai 2019. Menurut Eneng (2019), hakikat PKP adalah peningkatan kualitas lulusan peserta didik melalui pembelajaran di kelas dengan fokus kompetensi pedagogik yang 
dilaksanakan guru dalam kelompok kerja berbasis zonasi . Dalam PKP, peningkatan komptensi guru diproyeksikan 30\% sedangkan peningkatan kualitas lulusan peserta didik diproyeksikan 70\%. Inti dari Program Guru Pembelajar dan PKP adalah mewujudkan guru profesional sesuai dengan amanat Undang-Undang Nomor 20 Tahun 2003 tentang Sistem Pendidikan Nasional dan Undang-Undang Nomor 14 Tahun 2005 tentang Guru dan Dosen. Kondisi ideal itulah yang hendaknya dicapai oleh guru di setiap sekolah, termasuk guru di SMA Negeri 1 Kuta Selatan.

Faktanya, kondisi ideal itu belum sepenuhnya terwujud di SMA Negeri 1 Kuta Selatan. Lambannya kenaikan pangkat guru sejak diberlakukan Peraturan Menteri Negara Pendayagunaan Aparatur Negara dan Reformasi Birokrasi Nomor 16 Tahun 2009, mulai 1 Januari 2013 adalah bukti nyata. Banyak pula guru yang nyaris macet dalam kenaikan pangkat dan jabatan karena terganjal publikasi ilmiah dan karya inovasi. Guru juga terlambat mengurus DUPAK tahunan yang notabena untuk kepentingannya sendiri. Kondisi guru demikian berbanding terbalik dengan data prestasi para siswa sejak 2016 2019, yang mengalami peningkatan dari tahun ke tahun. Keberhasilan prestasi siswa itu telah penulis buatkan Best Practice dari 2016 - 2019. Best Practice yang penulis buat mendapat apresiasi dari Direktorat Jenderal Pembinaan Guru dan Tenaga Kependidikan Kementerian Pendidikan dan kebudayaan Republik Indonesia. Terbukti, praktik baik ini lolos sebagai finalis 4 kali berturut-turut, berkat prestasi yang diraih para siswa. Bahkan dua di antara Best Practice penulis diterbitkan dalam buku cetak dan on line oleh Direktorat Jenderal Guru dan Tenaga Kependidikan (2017, 2018). Kedua Best Practice penulis yang dibukukan Direktorat itu adalah Sekolah sebagai Objek Wisata Pendidikan (2017) dan Mendulang Prestasi dengan Taksu Cinta (2018). Semua Best Practice itu berkat prestasi siswa SMA Negeri 1 Kuta Selatan.

Pertanyaan tentu saja pantas diajukan kepada gurunya, “Mengapa prestasi para guru SMAN 1 Kuta Selatan lamban dalam kenaikan pangkat, sedangkan prestasi siswa semakin meningkat ?" Pertanyaan ini menarik dicermati karena guru menjadi teladan bagi murid. Selama ini, guru selalu mendampingi dan membina siswa untuk kompetisi, sedangkan gurunya sendiri nyaris tidak melakoni. Kompetisi sebenarnya bagian dari PKB bagi guru termasuk mengikuti berbagai kegiatan ilmiah di dalam berbagai forum ilmiah secara mandiri. Menyikapi kondisi itu, artikel ini membahas topik "Meningkatkan Kemampuan Guru Menulis Karya Tulis Ilmiah dengan Menghadirkan Guru Tamu di Sekolah" , dengan dua alasan. Pertama, lambannya kenaikan pangkat para guru SMA 
Negeri 1 Kuta Selatan perlu dilakukan pendampingan secara berkelanjutan melalui peningkatan kapasitas bersama guru tamu. Guru tamu sebagai analog dari dosen tamu di Perguruan Tinggi, adalah pengajar dari instansi lain (dinas pendidikan, LPMP, Perguruan Tinggi) yang didatangkan secara sadar dan sengaja untuk mengajar dalam waktu tertentu melalui workshop dan seminar dalam meningkatkan kompetensi guru melalui proses mentoring, pendampingan, dan konsultatif, baik secara daring maupun luring. Kedua, masih rendahnya budaya literasi di kalangan guru SMA Negeri 1 Kuta Selatan sehingga menghambat publikasi ilmiah dan karya inovatif mereka sebagai bagian dari PKB. Mereka cenderung mencari kerja sampingan yang lebih menjanjikan secara ekonomi daripada suntuk menggumuli dunia akademik yang memeras otak untuk kenaikan pangkat dengan kenaikan gaji yang tidak seberapa.

\section{Metode}

Pengumpulan data dalam penulisan artikel ini menggunakan studi pustaka, kuesioner, lembar pengamatan, wawancara. Metode studi pustaka dilakukan berdasarkan sumber referensi terkait dengan topik artikel ini. Kuesioner disebarkan kepada guru terkait kegiatan literasi dan kegiatan workshop/ seminar yang mendatangkan guru tamu di sekolah. Kuesioner terkait literasi untuk guru diasumsikan berkaitan dengan tradisi membaca dan menulis di kalangan guru yang berelasi pula dengan kehadiran guru tamu di sekolah. Kehadiran guru tamu di sekolah untuk memantik lahirnya karya publikasi ilmiah/karya inovatif guru. Observasi dilakukan dengan lembar pengamatan terhadap guru terkait dengan kehadiran guru tamu di SMAN 1 Kuta Selatan. Wawancara dilaksanakan untuk mengetahui pandangan guru dan siswa terkait dengan program guru tamu masuk di sekolah.

Keseluruhan data yang terkumpul dianalisis dengan teknik analisis deskriptif kualitatif. Analisis deskriptif kualitatif adalah teknik analisis data berdasarkan faktafakta yang ditemukan baik melalui pengamatan, kuesioner, wawancara, maupun studi pustaka selanjutnya diuraikan secara verbal. Analisis deskriptif kulitatif adalah cara mendeskripsikan fakta-fakta yang kemudian disusul dengan analisis (Ratna, 2004). Dengan metode ini, peneliti menguraikan, memberikan pemahaman, menafsirkan, dan memberikan penjelasan, serta menemukan makna dari data yang tersaji. 
Indikator keberhasilan dalam artikel ini dilihat dari peningkatan prestasi sekolah yang mencakup keberhasilan guru dalam kenaikan pangkat dan peningkatan prestasi siswa dalam berbagai kompetisi, yaitu :

1. Minimal 3 orang guru berhasil naik pangkat pada 2019

2. Minimal 6 guru menjadi pemakalah pada seminar akademik yang dilaksanakan oleh SMA Negeri 1 Kuta Selatan ;

3. Minimal 5 guru berhasil membuat Artikel Ilmiah yang dimuat pada jurnal ber-ISSN;

4. Respon guru terhadap kehadiran guru tamu minimal dengan kategori Baik berdasarkan skala Linkert;

5. Prestasi siswa dalam berbagai lomba akademik/nonakademik meningkat minimal $10 \%$ dari tahun sebelum PTS ini dilaksanakan. Sebelum PTS ini dilaksanakan medali yang diraih siswa sebanyak 53, maka peningkatannya minimal menjadi 58.

Untuk mengetahui respon guru terkait dengan kehadiran guru tamu yang direncanakan secara sadar dan sengaja digunakan skor berdasarkan skala Likert dengan lima katagori seperti tabel berikut ini.

Tabel 1 Skala Likert

\begin{tabular}{|l|l|}
\hline \multicolumn{1}{|c|}{ Rata Rata persentase } & \multicolumn{1}{c|}{ Kriteria } \\
\hline $91-100$ & Sangat baik \\
\hline $81-90$ & Baik \\
\hline $71-80$ & Cukup \\
\hline $61-70$ & Kurang \\
\hline $0 \leq 60$ & Sangat kurang \\
\hline
\end{tabular}

(Suharsimi Arikunto, Prosedur Penelitian, 1998)

\section{Hasil dan Pembahasan}

\section{Hasil Penelitian}

Penelitian Tindakan Sekolah (PTS) terdiri atas dua siklus dan masing-masing siklus terdiri atas 4 tahap yaitu perencanaan, tindakan, pengamatan dan refleksi. Dalam perencanaan teridentifikasi permasalahan yang dialami guru dan prediksi kemungkinan solusi. Berdasarkan data kepangkatan guru, sejak 1 Januari 2013 terjadi stagnasi kenaikan pangkat guru, saat mulai diberlakukanya Permen PAN dan RB Nomor 16 Tahun 2009 secara efektif. Sebelum itu, para guru terlena naik pangat dengan lancar, hampir setiap 2 tahun sekali. Oleh karena itu, selaku Kepala Sekolah, penulis merancang program 
mendatangkan guru tamu ke sekolah untuk menjadi mentor dan motivator bagi guru untuk mengembangkan Publikasi Ilmiah/Karya Inovatif.

Pada siklus I, perencanaan pembelajaran dilakukan melalui dua kali kegiatan yaitu workshop dan seminar, dengan total 5 kali pertemuan. Workshop dengan pola 32 Jam (4 hari) dilaksanakan terintegrasi dengan persiapan pembelajaran mengawali tahun pelajaran 2017/2018, yang dilaksanakan pada akhir Juli. Materi workshop antara lain Review dan Pengembangan Kurikulum, Pembelajaran dan Evaluasi dengan ikutannya, Pendidikan Karakter, Literasi, Pengembangan Diri, dan Publikasi Ilmiah/Karya Inovatif. Narasumber dari kegiatan workshop ini adalah para mentor yang dijadikan Guru Tamu, yaitu Dr. I Wayan Surata, M.Pd. dan Dr. Ni Made Suciani, M.Pd. (Widyaswara LPMP Bali), Dr. I Wayan Widana, M.Pd. (Dosen IKIP PGRI Bali), Dra. Luh Gede Budi Utami, M.Hum. (Pengawas Pendidikan Provinsi Bali) dan penulis sendiri, Dr. Drs. I Nyoman Tingkat, M.Hum. penulis sendiri selaku Kepala Sekolah.

Sebagai tindak lanjut dari workshop dilaksanakan Seminar Akademik sehari pada minggu ketiga bulan Oktober 2017 dengan tujuan mengevaluasi tindak lanjut workshop sekaligus memberikan kesempatan kepada para guru tampil di ranah akademik untuk menyeminarkan hasil-hasil penelitian, baik berupa Penelitian Tindakan Kelas (PTK) maupun Best Practices. Sesuai dengan petunjuk buku 5 tentang Pengembangan Profesi Guru, peserta seminar minimal melibatkan tiga SMA terdekat, yaitu SMA Negeri 1 Kuta Selatan, SMA Dwijendra Bualu, dan SMA Taman Rama Jimbaran dengan 5 pengawas.

Ketika kegiatan seminar ini pertama kali dilaksanakan, penulis mengalami kesulitan untuk mendapatkan guru yang mau menjadi pemakalah. Penulis harus merayu dan meyakinkan para guru untuk mau belajar dan kehadiran guru tamu bukan untuk menguji, tetapi memberikan masukan dan saran sekaligus jalan solusi untuk perbaikan. Walaupun demikian, guru tetap ketakutan. Akhirnya, penulis mengalah menjadi pemakalah dengan membawakan makalah Best Practice diikuti oleh dua Wakil Kepala Sekolah, Drs. I Gusti Putu Sunaya, M.Pd. (Wakil Kepala Sekolah bidang Kurikulum) dan I Ketut Suwita, S.Pd., M.Pd. (Wakil Kepala Sekolah bidang Sarana/Prasarana) yang membawakan makalah PTK.

Selama workshop dan seminar berlangsung teramati sejumlah guru kurang serius mengikuti kegiatan. Di antara mereka banyak yang memainkan HP dan senyum-senyum sendiri menyimak layar. Tidak jarang pula tampak berbincang dengan teman duduknya. Tidak fokus dengan materi workshop pun tidak intens dalam mengikuti seminar. Padahal 
workshop dan seminar ini dirancang untuk membantu guru dalam Pengembangan Diri melalui kegiatan kolektif. Laporan Pengembangan Diri pun tidak mereka kerjakan. Sebagai gambaran, respon guru terhadap kehadiran guru tamu dalam pelaksanaan workshop dan seminar akademik pada siklus I dapat dibaca dalam tabel 01.

Tabel 2 Respon Guru terhadap Kehadiran Guru Tamu pada Siklus I.

\begin{tabular}{|c|c|c|c|c|c|c|}
\hline No. & Pernyataan & SS & $S$ & $\mathrm{R}$ & TS & STS \\
\hline 1. & $\begin{array}{l}\text { Saya menggunakan Tunjangan Profesi Guru untuk } \\
\text { pengembangan literasi }\end{array}$ & 0 & 0 & 4 & 26 & 6 \\
\hline 2. & $\begin{array}{l}\text { Saya selalu membaca terkait dengan mata pelajaran } \\
\text { yang diampu }\end{array}$ & 4 & 5 & 4 & 15 & 8 \\
\hline 3. & $\begin{array}{l}\text { Saya selalu membaca terkait dengan informasi tentang } \\
\text { guru baik melalui media cetak maupun media on line }\end{array}$ & 1 & 2 & 3 & 16 & 14 \\
\hline 4. & $\begin{array}{l}\text { Saya selalu mengikuti perkembangan mutakhir seputar } \\
\text { pendidikan }\end{array}$ & 1 & 1 & 5 & 20 & 9 \\
\hline 5. & $\begin{array}{l}\text { Saya berlangganan internet/Koran untuk mendukung } \\
\text { Pengembangan Keprofesian Berkelanjutan }\end{array}$ & 5 & 6 & 3 & 18 & 4 \\
\hline 6. & $\begin{array}{l}\text { Saya memanfaatkan kegiatan seminar akademik yang } \\
\text { mendatangkan guru tamu untuk mengembangkan } \\
\text { profesi }\end{array}$ & 11 & 15 & 1 & 6 & 4 \\
\hline 7. & $\begin{array}{l}\text { Saya memanfaatkan kehadiran guru tamu dalam } \\
\text { workshop untuk menyusun karya tulis ilmiah }\end{array}$ & 9 & 17 & 2 & 7 & 2 \\
\hline 8. & $\begin{array}{l}\text { Saya percaya diri sebagai pemakalah saat tampil dalam } \\
\text { seminar akademik yang di-review oleh guru tamu }\end{array}$ & 9 & 7 & 1 & 10 & 9 \\
\hline 9. & $\begin{array}{l}\text { Saya memiliki pemahaman yang lebih baik setelah } \\
\text { mengikuti arahan guru tamu terkait dengan publikasi } \\
\text { ilmiah untuk kenaikan pangkat/jabatan }\end{array}$ & 8 & 18 & 2 & 6 & 2 \\
\hline 10. & $\begin{array}{l}\text { Saya termotivasi membaca dan menulis setelah } \\
\text { kehadiran guru secara rutin dalam workshop dan } \\
\text { seminar yang diadakan sekolah }\end{array}$ & 6 & 20 & 1 & 8 & 1 \\
\hline
\end{tabular}

Dari 10 item pernyataan dalam tabel 05, pernyataan 1 - 5 mengacu pada tingkat literasi guru, sedangkan 6 - 10 mengacu pada respon terhadap kehadiran guru tamu. Kalau dikategorikan rerata literasi guru berdasarkan pernyataan 1 - 5 yang diperoleh dari penjumlahan pernyataan SS (Sangat Setuju) dan S (Setuju) dibagi 5, maka akan 
diperoleh tingkat literasi guru hanya mencapai 13,88 \% (sangat kurang). Selanjutnya, respon guru terhadap guru tamu berdasarkan pernyataan 6 - 10 dari pernyataan SS dan S diperoleh 77,22 \% dengan kategori cukup.

Dengan demikian, pada Siklus I kehadiran guru tamu belum mampu menjawab kriteria keberhasilan sesuai dengan indikator yang dtetapkan. Dari target 3 orang guru dapat naik pangkat tidak satu pun guru berhasil mencapainya. Selanjutnya, target minimal 6 guru berhasil membuat proposal Publikasi Ilmiah/Karya inovatif yang siap untuk ditampilkan dalam seminar akademik hanya terpenuhi 3 orang guru. Itu pun dilakukan oleh staf pimpinan sekolah termasuk Kepala Sekolah. Dengan kata lain hanya mampu mencapai $50 \%$ dari target kriteria keberhasilan. Selanjutnya, guru yang berhasil artikel ilmiahnya dimuat pada jurnal ilmiah ber-ISSN hanya 4 orang (80 \%) pada tahun 2017/2018 dan belum memenuhi target dari 5 orang yang ditargetkan sesuai dengan indikator keberhasilan untuk publikasi ilmiah. Sementara itu, dari kuesioner yang disampaikan, dari 36 guru PNS yang merespon positip terhadap kehadiran guru tamu hanya mencapai 72,22 \% dengan kategori Cukup dari kategori Baik minimal yang ditetapkan $81 \%$.

Pada siklus II, proses pembelajaran juga berlangsung melalui workshop dengan pola 32 jam selama 4 hari pada awal tahun pelajaran 2018/2019 dan seminar akademik sehari pada 22 Oktober 2018. Narasumber dari kegiatan workshop dan reviewer dalam seminar ini sama dengan narasumber workshop pada siklus I. Jika pada siklus I penyajian materi murni disampaikan secara akademik penuh dengan keseriusan pada siklus II narasumber menyelingi kejenuhan peserta dengan ice breaking yang inspiratif dan menyegarkan yang mampu mengusir kejenuhan. Tampak peserta workshop terjaga semangat dan konsentrasinya setelah ice breaking. Hal ini juga mengonfirmasi bahwa setiap manusia perlu variasi dalam hidup agar tidak tersandera dalam rutinitas yang menjenuhkan. Sebagai gambaran, respon guru terhadap kehadiran guru tamu pun makin positip, sebagaimana terbaca dari tabel 02 .

Tabel 2 Respon Guru terhadap Guru Tamu pada Siklus II

\begin{tabular}{|l|l|l|l|l|l|l|}
\hline No. & Pernyataan & SS & S & R & TS & STS \\
\hline 1. & $\begin{array}{l}\text { Saya menggunakan Tunjangan Profesi Guru untuk } \\
\text { pengembangan literasi }\end{array}$ & 2 & 3 & 4 & 26 & \\
\hline 2. & $\begin{array}{l}\text { Saya selalu membaca terkait dengan mata pelajaran } \\
\text { yang diampu }\end{array}$ & 7 & 10 & 2 & 10 & 7 \\
\hline
\end{tabular}




\begin{tabular}{|l|l|l|l|l|l|l|}
\hline 3. & $\begin{array}{l}\text { Saya selalu membaca terkait dengan informasi } \\
\text { tentang guru baik melalui media cetak maupun } \\
\text { media on line }\end{array}$ & 4 & 8 & 2 & 10 & 12 \\
\hline 4. & $\begin{array}{l}\text { Saya selalu mengikuti perkembangan mutakhir } \\
\text { seputar pendidikan }\end{array}$ & 5 & 6 & 1 & 18 & 6 \\
\hline 5. & $\begin{array}{l}\text { Saya berlangganan internet/Koran untuk } \\
\text { mendukung Pengembangan Keprofesian } \\
\text { Berkelanjutan }\end{array}$ & 8 & 9 & 3 & 11 & 5 \\
\hline 6. & $\begin{array}{l}\text { Saya memanfaatkan kegiatan seminar akademik } \\
\text { yang mendatangkan guru tamu untuk } \\
\text { mengembangkan profesi }\end{array}$ & 13 & 17 & 1 & 3 & 2 \\
\hline 7. & $\begin{array}{l}\text { Saya memanfaatkan kehadiran guru tamu dalam } \\
\text { workshop untuk menyusun karya tulis ilmiah }\end{array}$ & 14 & 16 & 0 & 4 & 2 \\
\hline 8. & $\begin{array}{l}\text { Saya percaya diri sebagai pemakalah saat tampil } \\
\text { dalam seminar akademik yang di-review oleh guru } \\
\text { tamu }\end{array}$ & 11 & 9 & 2 & 9 & 5 \\
\hline 9. & $\begin{array}{l}\text { Saya memiliki pemahaman yang lebih baik setelah } \\
\text { mengikuti arahan guru tamu terkait dengan } \\
\text { publikasi ilmiah untuk kenaikan pangkat/jabatan } \\
\text { kehadiran guru secara rutin dalam workshop dan } \\
\text { seminar yang diadakan sekolah }\end{array}$ & 10 & 20 & 1 & 3 & 2 \\
\hline Saya termotivasi membaca dan menulis setelah & 8 & 22 & 1 & 4 & 1 \\
\hline
\end{tabular}

Dari 10 item pernyataan dalam tabel 05, pernyataan $1-5$ mengacu pada tingkat literasi guru, sedangkan 6 - 10 mengacu pada respon terhadap kehadiran guru tamu. Kalau dikategorikan rerata literasi guru berdasarkan pernyataan 1 - 5 yang diperoleh dari penjumlahan pernyataan SS (Sangat Setuju) dan S (Setuju) dibagi 5 , maka diperoleh rerata tingkat literasi guru pada siklus II mencapai 34,44 \% (sangat kurang). Selanjutnya, respon guru terhadap guru tamu berdasarkan pernyataan 6 - 10 dari pernyataan SS dan S diperoleh 83,33 \% dengan kategori Baik. Dibandingkan dengan siklus I ada kenaikan tingkat literasi guru sebesar 20,56 \% dan kenaikan respon guru sebesar 11,11\% pada siklus II.

Rendahnya literasi guru terkonfimasi pula dalam wawancara yang dilakukan. Pada siklus I teridentifikasi bahwa tak satu pun guru menggunakan TPG-nya 
mengembangkan literasi. Bahkan dari wawancara juga terpotret bahwa hutang guru meningkat seiring dengan pendapatan TPG. Hal ini berbanding terbalik dengan tugas guru yang selalu mengampanyekan Gerakan Literasi Sekolah (GLS) dengan para siswa. Dari wawancara yang dilakukan terhadap siswa tergambar pula wawasan guru dalam pemelajaran. Siswa pun merasakan dampaknya antara guru literat dan kurang literat dalam proses pemelajaran.

Meskipun demikian, PTS ini menunjukkan ada korelasi positip antara tingkat literasi guru dengan respon terhadap guru tamu. Selain memberikan materi penguatan terkait dengan topik workshop kepada peserta, narasumber yang menjadi guru tamu juga menunjukkan hasil review-nya terhadap beberapa naskah yang berhasil diterbitkan dalam jurnal Didaktika terbitan SMA Negeri 1 Kuta Selatan dengan ISSN Nomor 2461-1239. Walaupun tidak banyak di antara peserta yang berhasil dimuat artikelnya di jurnal ini, cukup memberikan penguatan kepada peserta workshop untuk berproses. Yang terpenting lagi bagi peserta workshop adalah pemahamannya tentang proses berkarya yang memerlukan ketekunan dan kesungguhan berliterasi sesuai dengan konsep belajar sepanjang hayat.

Selanjutnya, dengan memberikan kerangka sistematika laporan Pengembangan Diri, peserta workshop juga ditantang untuk menyelesaikannya setelah workshop berakhir sehingga guru tidak terbebani lagi ke rumah masing-masing. Hasilnya, para guru berhasil menuntaskan laporannya. Pekerjaan selesai di ruang workshop. Begitulah pembelajaran pada workshop siklus II berlangsung menyenangkan dan inspiratif. Peserta bekerja secara aktif sesuai dengan tagihan dalam workshop dan suasana hening dan khusuk terasa, dengan sesekali muncul celetukan peserta yang mengundang tawa. Suasana workhop berlangsung sangat cair dan hangat antara guru tamu dengan para guru. Sesekali guru tamu berkeliling mendekati masing-masing peserta mengerjakan tugas dan memberikan arahan individu.

Selanjutnya, pada saat seminar peserta yang membawakakan makalah mengalami peningkatan drastis dari 3 orang pada siklus I menjadi 8 orang pada siklus II. Jika pada siklus I pemakalah harus dirayu agar mau tampil dan nyatanya tidak ada yang berani sehingga penulis selaku kepala sekolah dan dua wakil Kepala Sekolah menjadi pioner untuk memulai dan menjadi contoh terlepas dari segala kekurangannya. Dengan contoh dari staf pimpinan sekolah pada siklus I, pada siklus II ada 8 guru yang mengajukan diri tampil sebagai pemakalah dengan sebaran jenis publikasi ilmiah yang 
variatif, tidak hanya PTK tetapi juga Best Practice dan PTS. Kenyataan ini menunjukkan bahwa PKB bagi guru perlu ada contoh dan teladan dari pimpinan sekolah.

Pada saat seminar, peserta pun bertambah dari tiga SMA pada siklus I menjadi empat SMA pada siklus II. Peserta tampak semangat dan bertahan dari awal sampai akhir Seminar. Walaupun ada satu dua guru meninggalkan ruang seminar sebelum berakhir, mereka telah mengonfirmasi panitia karena tugas yang tidak bisa ditinggalkan. Perwakilan empat SMA yang mengikuti seminar yaitu SMA Negeri 1 Kuta Selatan, SMA Negeri 2 Kuta, SMA Dwi Jendra Bualu, dan SMA Taman Rama Jimbaran. Partisipasi dari SMA lain menunjukkan jalinan kerjasama dengan semangat gotong royong dan selalu berkolaborasi melalui proses komunikasi intensif, untuk mewujudkan sikap berpikir kritis melalui seminar akademik, sesuai dengan tuntutan keterampilan abad ke-21 dengan $4 \mathrm{~K}$ (berpikir kritis, kolaborasi, komunikasi, dan kreativitas/inovasi). Perhatian peserta pun tampak serius dan bersungguh-sungguh menyimak presentasi para pemakalah dan masukan dari guru tamu sebagai narasumber.

\section{Refleksi Pembelajaran antarsiklus}

Pada siklus I, saat worshop dan seminar dimulai, para guru SMA Negeri 1 Kuta Selatan kompak memasuki ruangan. Bahkan sangat semangat menunggu acara pembukaan workshop dan seminar yang dibuka oleh Kepala Bidang Pembinaan Guru dan Tenaga Kependidikan Provinsi Bali. Acara workshop yang diawali dengan menyanyikan lagu Indonesia Raya terasa sangat khusuk diikuti seluruh peserta. Begitu pula saat doa dikumandangkan setelah Indonesia Raya. Para peserta tampak bersemangat dan fokus. Fokus para peserta workshop juga sampai pada acara pembukaan yang dibuka oleh Drs. I Wayan Suarna, M.Si. selaku Kepala Bidang Pembinaan Guru dan Tenaga Kependidikan (GTK) Dinas Pendidikan Provinsi Bali. Pada intinya, Kepala Bidang pembinaan GTK mengingatkan para guru selalu menjaga disiplin, menguatkan lima nilai utama karakter bangsa, menyukseskan program literasi sekolah, dan terus- menerus belajar sepanjang hayat. Fokus melakukan kegiatan PKB seperti melalui workshop ini dan seminar yang telah dirancang pihak sekolah. "Jika guru ingin naik pangkat, mau tidak mau harus melakukan pengembangan diri dan publikasi ilmiah/karya inovatif. Ini amanat Permeg PAN dan RB Nomor 16 Tahun 2009. Oleh karena itu, guru mesti belajar sepanjang karier dengan mengikuti perkembangan ilmu dan teknologi yang bergerak cepat dan selalu menyesuaikan diri dengan para siswa yang dikenal sebagai generasi Z oleh Stillman", demikian Kabid GTK mengingatkan para guru. 
Selesai acara pembukaan dilanjutkan dengan sesi penyajian materi sampai istirahat makan siang. Para peserta masih tampak serius. Setelah rehat makan siang, kelesuan mulai tampak. Satu persatu guru meninggalkan ruangan dan tidak kembali walaupun workshop sedang berlangsung. Ini bukti ketidaktertarikan para guru dengan kegiatan akademik. Mereka meninggalkan ruangan tanpa izin. Sesuatu yang paradok sebab guru selalu menertibkan siswa untuk menaati tatatertib sekolah. Hal serupa juga terjadi saat Seminar Akademik digelar pada bulan 21 Oktober 2017 menjelang HUT ke-18 SMA Negeri 1 Kuta Selatan. Dari 36 guru PNS di SMA Negeri 1 Kuta Selatan, tidak lebih dari 18 orang (50\%) yang masih bertahan di ruang seminar sampai berakhir. Padahal seminar juga diikuti oleh para guru dari SMA Dwijendra Bualu dan SMA Taman Rama Jimbaran. Menjadi peserta seminar saja belum sanggup, bagaimana mungkin bisa bertahan dan berjibaku melahirkan proposal penelitian untuk selanjutnya diseminarkan.

Berhadapan dengan kondisi itu, penulis sebagai Kepala Sekolah bersama guru tamu merancang program workshop dan Seminar setahun sebelumnya dengan menyiapkan guru untuk menulis proposal penelitian Publikasi Ilmiah/Karya Inovatif melalui bimbingan secara on line dengan mentor guru tamu. Bimbingan on line ini dilakukan setelah guru yang dipersiapkan menulis proposal. Jadi, guru tetap dituntut berkarya sebelum melakukan bimbingan dengan respon cepat dari guru tamu.

Dengan cara itu, proses belajar pada siklus II mengalami perubahan secara siginfikan ke arah positip walaupun kecil dibandingkan dengan proses belajar siklus I. Hal ini tampak dari semangat dan keseriusan peserta workshop dan peserta seminar akademik. Terjadi interaksi multi arah antara guru tamu ke peserta dan peserta dengan peserta saat workshop berlangsung, baik pada pertemuan pertama, kedua, ketiga, dan keempat, maupun saat seminar berlangsung. Dialog berjalan secara edukatif fungsional dengan saling memberi dan menerima di antara para peserta. Suasana pembelajaran berlangsung hangat dan kondusif. Tidak terlihat sekat antara guru tamu dengan para peserta. Mereka tampak dengan semangat, "Semua murid semua guru", antara guru tamu dengan peserta.

Di balik interaksi yang cair itu, tampak nilai-nilai utama karakater terimplementasikan : gotong royong, integritas, religious, nasional, dan mandiri. Di samping itu, nilai-nilai keberagaman dan demokrasi tersirat pula dalam sesi pembelajaran. Pada sesi seminar, kekeliruan juga masih tampak. Namun, segera disadari oleh pemakalah yang menyajikan makalahnya. Makalah yang ditampilkan para peserta 
juga tidak monoton PTK, tetapi juga Best Practices dan Penelitian Tindakan Sekolah (PTS). Hal ini juga mengonfirmasi, para guru di SMA Negeri 1 Kuta Selatan, tidak melulu berPTK dalam PKB, tetapi juga menghasilkan bentuk-bentuk publikasi ilmiah yang beragam. Bahkan di antara para guru juga membuat modul pembelajaran dan artikel yang dimuat di Jurnal Didaktika yang diterbitkan SMA Negeri 1 Kuta Selatan dan Jurnal Kompetensi yang dikelola Dinas Pendidikan Provinsi Bali.

\section{Pembahasan}

Dari hasil penelitian yang telah dilaksanakan terjadi perubahan positip dari siklus I ke siklus II. Pada siklus I, kehadiran guru tamu belum mampu secara optimal memberdayakan guru dalam menulis karya ilmiah. Beberapa kemungkinan penyebabnya adalah (1) model bimbingan karya tulis yang dilakukan identik dengan bimbingan skripsi dan seminarnya disaksikan oleh guru beramai-ramai sehingga menimbulkan ketakutan; (2) guru belum terbiasa berkolaborasi sehingga malu dilihat kemampuannya oleh sesama guru; (3) guru .kurang motivasi untuk menulis karya ilmiah karena rendahnya literasi; (4) guru suntuk beradministrasi untuk memenuhi tuntutan birokrasi sehingga tidak tersedia cukup waktu untuk berpikir kritis dengan menulis karya ilmiah yang sebenarnya bertujuan untuk meningkatkan hasil pembelajaran.

Dengan menggunakan pendekatan humanistik pada siklus II, kehadiran guru tamu di SMA Negeri 1 Kuta Selatan berhasil membangun komunikasi secara cair. Komunikasi berjalan setara sebagaimana layaknya teman ngobrol secara informal tanpa sekat saling mengisi melalui dialog edukatif fungsional. Sesekali diselingi humor dan ice breaking yang mencairkan suasana. Model komunikasi ini sejalan dengan teori Humanistic Education dari Abraham Maslow. Menurutnya, pembelajaran yang berlangsung dalam suasana penuh kasih sayang, hangat, hormat, dan terbuka memungkinkan terjadinya transfer pengetahuan secara alami tanpa tekanan (Rachmahana, 2008). Selain itu, dengan pendekatan humanistik, proses komunikasi antara guru tamu dengan para guru SMA Negeri 1 Kuta Selatan mengedepankan nilai-nilai edukatif yang memanusiakan dan memberadabkan dengan titik poin pada pesrsuasi, identifikasi, dan solusi (PIS)(Tingkat, 2018).

Pendekatan itu berhasil meningkatkan prestasi guru SMA Negeri 1 Kuta Selatan yang ditandai dengan kenaikan pangkat guru, keberanian guru tampil dalam seminar akademik, keberhasilan guru menulis di jurnal ilmiah ber-ISSN yang berdampak pada 
peningkatan prestasi siswa. Keberhasilan ini juga sejalan dengan hasil penelitian Riansyah (2009), Tegeh, dkk. (2012), Sari, dkk. (2013), Tingkat (2016; 2019), dan Widana, dkk. (2019). Pada intinya, penelitian mereka menemukan bahwa pendampingan terhadap guru dalam membuat karya tulis ilmiah umumnya berhasil secara positip karena guru tamu mempraktikkan interaksi belajar yang empati, wajar, respek, komitmen, mengakui kehadiran orang lain, membuka diri, dan tidak menggurui. Hal ini sejalan dengan cara pendidikan orang dewasa yang disebut pendidikan andragogi, yang mengepankan caracara yang manusiawi dengan menjadikan guru sebagai teman yang setara dan saling membelajarkan secara edukatif fungsional.

\section{Kesimpulan}

Simpulan yang dapat ditarik sesuai dengan permasalahan yang telah dibahas ada dua. Pertama, kehadiran guru tamu melalui workshop di SMA Negeri 1 Kuta Selatan dapat meningkatkan kemampuan guru untuk menulis karya tulis ilmiah dan karya inovatif. Implikasinya berdampak pada kenaikan pangkat para guru dari 0 pada sikus I menjadi 3 orang $(7,69 \%)$ pada Siklus II. Guru yang membuat proposal dan siap tampil dalam Seminar Akademik meningkat dari 3 orang $(7,69)$ pada Siklus I menjadi 8 orang $(20,51 \%)$ pada Siklus II. Guru yang menulis artikel ilmiah di jurnal ber-ISSN meningkat dari 4 orang $(10,25 \%)$ pada Siklus I menjadi 5 orang $(12,82 \%)$ pada Siklus II. Simpulan ini sesuai dengan kriteria keberhasilan yang ditetapkan dalam metode penelitian. Kedua, respon guru juga mengalami peningkatan terhadap kehadiran guru tamu dari 72,22 \% dengan kategori Cukup pada Siklus I menjadi 83,33 \% dengan kategori Baik pada Siklus II. Meningkatnya respon positip guru juga dapat meningkatkan prestasi siswa, dari 72 medali pada Siklus I menjadi 88 medali pada Siklus II.

\section{Daftar Pustaka}

Depdikbud.2002 .Kamus Besar Bahasa Indonesia.Jakarta : PN Balai Pustaka.

Kemendiknas. 2009. Peraturan Menteri Negara Pendayagunaan Aparatur Negara dan Reformasi Nomor 16 Tahun 2009 tentang Jabatan Fungsional Guru dan Angka Kreditnya. Jakarta.

Kumalasari, Dyah dkk. 2003. Pelatihan dan Pendampingan Penulisan Karya Ilmiah Sejarah Berwawasan Pendidikan Karakter.Yogyakarta : LP2M UNY. 
Ratna, I Nyoman Kutha. 2004. Teori, Metode, dan Teknik Penelitian Sastra dari Strukturalisme hingga Poststrukturalisme. Yogyakarta : Pustaka Pelajar.

Ryansah, Jati. 2009. "Pendekatan Andragogi dalam Diklat" dalam Blogspot.co.id (diakses 9 Juli 2016).

Rachmahana, R. S. (2008). Psikologi Humanistik dan Aplikasinya dalam Pendidikan. ElTarbawi Jurnal Pendidikan Islam, 1.

Ratna, I. N. K. (2004). Metode, dan Teknik Penelitian Sastra dari Strukturalisme hingga Poststrukturalisme. Yogyakarta: Pustaka Pelajar.

Suharmini Arikunto, 1998. Prosedur Penelitian. Jakarta : Rineka Cipta.

Susilawati, Eneng. 2019. Peningkatan Kompetensi Pembelajaran. (Power Point). Bandung : P4TK IPA.

Tegeh, I Made. 2012. Pendampingan Pelaksanaan Penelitian Pengembangan bagi Guru-guru SD di Kota Singaraja. Singaraja : LP2M Undiksha.

Tingkat, I. N. (2018). Mendulang Prestasi dengan Taksu Cinta.

Widana, I Wayan. 2019. Penerapan Metode Simpang Tegar (Sosiasilasi dan Pendampingan Terintegrasi) untuk Meningkatkan Kemampuan Guru dalam Menulis PTK dan Artikel Ilmiah di SMAN 1 Selemadeg dan SMAN 1 Kerambitan. (Laporan Penelitian). Denpasar : IKIP PGRI. 